\title{
Trunk asymmetry at children aged 10-15 years: relation between amount of asymmetry and risk factors.
}

\author{
Béla József BALLA', IacobHANŢIU²
}

\begin{abstract}
Objective: This study focuses on the possible associations between the trunk asymmetry (TA) and different risk factors, such as: Body Mass Index (BMI), place of residence (rural/urban area), the gender of the subjects and the level of the physical activity.

Methods: The data for this study was obtained from a cross-sectional survey of school children carried out in 2015 in ClujNapoca, Romania. In this study 487 pupils (260 boys and 227 girls) aged 10-15 years were included. The angle of trunk rotation (ATR) was obtained from scoliometer readings. The level of the physical activity was calculated from the Physical Activity Questionnaire for Older Children. The statistical analysis was carried out on the obtained mean values (independent sample t-test, paired-sample t-test, ANOVA), and the relation between variables was analyzed by the Pearson correlation coefficient.

Results: In case of subjects from urban area the degree of TA was $2.75^{\circ}\left( \pm 2.85^{\circ}\right)$, and in case of those from rural area $2.09^{\circ}\left( \pm 2.23^{\circ}\right), t=2.813, p=0.005$. The TA was lower in subjects who live in rural area, in houses: $2.07^{\circ}( \pm 2.21)$, than in case of those who live in flats in urban area: $2.86^{\circ}( \pm 2.94),(p=0.032)$. The level of physical activity in case of boys is higher than in case of girls (boys $2.82 \pm(0.68)$, girls $2.62( \pm 0.67)$ ). The Pearson correlation test did not find any correlation between the angle of trunk rotation and the level of physical activity: $r=0.000, p=0.998$. The degree of TA is higher in case of girls, than in case of boys (girls $2.88^{\circ}\left( \pm 2.91^{\circ}\right.$ ), boys $2.19^{\circ}\left( \pm 2.38^{\circ}\right)$ ), $\mathrm{t}=-2.601, p=0.010$. However, we found small correlation between the BMI and the TA in case of boys who have a degree of trunk asymmetry $\geq 5^{\circ}: r=-0.289, p=0.044$.

Conclusions: The study revealed the lack of correlation between the TA and BMI, place of residence and the level of physical activity practiced. However, in case of boys we found a small correlation between the BMI and sever asymmetry.

Key words: trunk asymmetry, scoliosis, children aged 10-15, physical activity.
\end{abstract}

\section{Rezumat}

Scop: Acest studiu se axează pe investigarea unor relații posibile între asimetria spatelui (AS) și diferiți factori favorizanți, cum ar fi: indicele de masă corporală (IMC), mediul de reședință, genul subiecților și nivelul activității fizice.

Metode: Datele acestui studiu transversal au fost obținute în urma unui screening școlar efectuat în anul 2015 în Cluj Napoca ( România). În studiu au fost incluși 487 elevi (260 băieți și 227 fete) cu vârste cuprinse între 10-15 ani. Asimetria spatelui a fost evaluată prin măsurarea unghiului de rotație al spatelui, cu ajutorul unui scoliometru. Pentru determinarea nivelului activității fizice a subiecților a fost aplicat chestionarul Physical Activity Questionnaire for Older Children (PAQ-C) elaborat în 1997. Datele înregistrate au fost analizate statistic prin compararea valorilor medii (testul t pentru eșantioane independente și pentru un singur eșantion, testul ANOVA), iar relațiile dintre variabile cu ajutorul coeficientului de corelație (corelație liniară Pearson).

Rezultate: AS la subiecții din mediul urban a fost de $2.75^{\circ}\left( \pm 2.85^{\circ}\right)$, iar în cazul celor din mediul rural de $2.09^{\circ}\left( \pm 2.23^{\circ}\right), t=$ $2.813, p=0.005$. Mărimea asimetriei a fost mai mică la subiecții care locuiesc în mediul rural la casă 2.07으 ( \pm 2.21$)$, decât la cei care locuiesc în mediul urban la bloc: $2.86^{\circ}( \pm 2.94),(p=0.032)$. Nivelul activității fizice al băieților $2.82 \pm(0.68)$ este mai mare, decât al fetelor 2.62 $( \pm 0.67)$. Testul de corelație Pearson nu a găsit corelație dintre unghiul de rotație al spatelui și nivelul activității fizice: $r=0.000, p=0.998$. AS este mai mare la fete $2.88^{\circ}\left( \pm 2.91^{\circ}\right)$, decât la băieți $2.19^{\circ}\left( \pm 2.38^{\circ}\right), \mathrm{t}=-2.601, p$ $=0.010$. S-a constatat că există corelație foarte slabă, între IMC și AS în cazul băieților care au asimetrii $\geq 5$ o: $r=-0.289, p=$ 0.044 .

Concluzii: Studiul a relevat lipsa de corelație dintre asimetria spatelui și IMC, genul subiecților, mediul de reședință sau nivelul de activitate fizică practicată. Totuși, la băieți s-a constatat o corealație slabă între IMC și asimetria gravă.

Cuvinte cheie: asimetria spatelui, scolioză, copii de 10-15 ani, activitate fizică.

${ }^{1}$ PhD Student, Universiy of Babeș-Bolyai, Cluj-Napoca, Romania, Faculty of Physical Education and Sport, e-mail:balla bela jozsef@yahoo.com ${ }^{2}$ Prof., University of Babeș-Bolyai, Cluj-Napoca, Romania, Faculty of Physical Education and Sport 


\section{Introduction}

The trunk asymmetry is a common physical disability in school age-children[1].It's prevalence, as well as the deficiencies of the locomotor system depend on several factors, among which: accidents, genetic factors, nutritional factors, lifestyle, lack of physical activity, psychological problems, etc.[2],as well as gender, age, residence area or the physical activity level of the subjects [3,4].We should focus on this postural problem, because this is the strongest factor that indicates the presence or predisposition to a scoliotic curvature [5].This fact is demonstrated by several studies, that find correlation between the truncal asymmetry and the scoliotic curvature $(>10$ Cobb degrees) in childhood and adolescence [6]. In order to measure the back trunk asymmetry several different methods were developed, but the most commonly used is the clinical examination using a scoliometer, especially when a school screening program is performed [7]. This type of examination method has multiple advantages: 1) the scoliometer is easy to use, 2) it is a cost effective tool and screening method[8]; 3) the evaluation can be performed in a relatively short time on a large sample, 4) it is not necessary for the examiner to have a medical qualification, 5) the method provides relatively reliable results [9]

The purpose of this study was to identify associations between trunk asymmetry and other various factors, such as body mass index (BMI), residence area (rural / urban), gender of the subject and physical activity level.

\section{Materials and methods}

\section{Subjects}

The study was conducted between March and May 2015 in three schools: one in Sălajcounty (rural school) and two in Cluj county (urban schools). The sample included 487 children age 10-15 years, 227 girls (46.7\%) and 260 boys (53.3\%). The sample was selected using the convenient non-probabilistic sampling method. The children who were included in this study were examined during a school screening of
scoliosis.The trunk asymmetry was quantified by measuring the angle of trunk rotation at mid-thoracic $\left(\mathrm{T}_{4}-\mathrm{T}_{8}\right)$, thoraco-lumbar $\left(\mathrm{T}_{12}-\mathrm{L}_{1}\right)$ and at the lumbar $\left(\mathrm{L}_{2}-\right.$ $\left.\mathrm{L}_{5}\right)$ regions of the spine.

\section{Instruments and the measuring procedure}

The Physical Activity Questionnaire for Older Children (PAQ-C) developed by Kowalski, Crocker and Faulkner was used to determine the level of physical activity, suitable for pupils age 10-15 [10].

To obtain additional information on the sociodemographic data of the subjects, the questionnaire was completed with seven new questions. The time required to complete the questionnaire was between 15-20 minutes. Respondents were rated by the same person.

Measurements of waist, body mass and trunk asymmetry were performed using Secatalimeter, Beurer BG 17 digital scale and a GIMA scoliometer, which is an instrument designed and introduced in practice by Bunnell in 1984, to limit the subjectivity of the forward bending test (Adam's test) [11]. It is used for rapid quantification of the angle of trunk rotation. The angle of rotation should be measured at three levels of the spine: at thoracic vertebrae T4-T8, at the limit of the thoracic and lumbar region T12-L1 and at lumbar vertebrae L3-5.

The recorded results were statistically analyzed using the Statistical Package for Social Sciences (SPSS-v.20). The Pearson linear correlation test was performed, and the mean difference between the average values was tested with the t-Test and ANOVA.

\section{Results}

Measurements performed with the scoliometer revealed that symmetry is present in $44.5 \%$ of subjects, mild asymmetry in $45.6 \%$ and severe asymmetry in $9.9 \%$ of those evaluated.

More than $70 \%$ of the boys and $69 \%$ of the girls show symmetry in the thoracic region of the spine in standingforward bending position. The thoracolombar region is symmetric in $67.3 \%$ of the boys and in $60.3 \%$ of the girls (Table I).

Severe asymmetry in the thoracic region was found in $0.5 \%$ of boys and $6.9 \%$ of girls. In the thoracolombar region, severe asymmetry was found in 3.0\% of boys and $10.3 \%$ of girls, also in the lumbar region the percent of asymmetry was $2.0 \%$ in boys and $4.6 \%$ in girls. 
Table I. - Frequency of trunk asymmetryi $\mathrm{n}$ boys and girls

\begin{tabular}{lccc} 
& \multicolumn{3}{c}{ Boys } \\
\cline { 2 - 4 } $\begin{array}{l}\text { Regions of } \\
\text { the spine }\end{array}$ & $\begin{array}{c}\text { Symmetric } \\
{[\%]}\end{array}$ & $\begin{array}{c}\text { Mild } \\
\text { Asymmetry } \\
{[\%]}\end{array}$ & $\begin{array}{c}\text { Asymmetry } \\
{[\%]}\end{array}$ \\
\hline Thoracic & 70.85 & 28.65 & 0.50 \\
Thoracolumbar & 67.30 & 29.70 & 3.00 \\
Lumbar & 73.37 & 24.63 & 2.00 \\
\hline Mean & 70.51 & 27.66 & 1.84 \\
& & Girls & \\
Thoracic & 68.97 & 24.13 & 6.90 \\
Thoracolumbar & 60.34 & 29.32 & 10.34 \\
Lumbar & 70.69 & 24.71 & 4.60 \\
\hline Mean & 66.67 & 26.05 & 7.28
\end{tabular}

In the case of the urban sample, the meanasymmetry is $2.75^{\circ}\left( \pm 2.85^{\circ}\right)$ and in the rural sample $2.09^{\circ}\left( \pm 2.23^{\circ}\right)$, the significance test result is $t=2.813, p=0.005$. Similarly, the girls were found to have higher values of trunk asymmetries $\left(2.88^{\circ} \pm 2.91^{\circ}\right)$ than boys $\left(2.19^{\circ} \pm\right.$ $\left.2.38^{\mathrm{o}}\right), \mathrm{t}=-2.809, \mathrm{p}=0.005$.

Table II. The distribution of the subjects according to age

\begin{tabular}{cccc}
$\begin{array}{c}\text { Age } \\
\text { [years] }\end{array}$ & $\begin{array}{c}\text { Number } \\
\text { of ex. } \\
\text { Subjects }\end{array}$ & $\begin{array}{c}\text { Boys } \\
\text { Percent } \\
{[\%]}\end{array}$ & $\begin{array}{c}\text { Cumulative } \\
\text { percent [\%] }\end{array}$ \\
\hline 10 & 23 & 8.8 & 8.8 \\
11 & 41 & 15.8 & 24.6 \\
12 & 52 & 20 & 44.6 \\
13 & 57 & 21.9 & 66.5 \\
14 & 67 & 25.8 & 92.3 \\
15 & 20 & 7.7 & 100 \\
\hline \multicolumn{5}{c}{$\mathrm{N}=260$}
\end{tabular}

$\underline{\text { Girls }}$

\begin{tabular}{cccc}
10 & 35 & 15.4 & 15.4 \\
11 & 46 & 20.3 & 35.7 \\
12 & 45 & 19.8 & 55.5 \\
13 & 38 & 16.7 & 72.2 \\
14 & 49 & 21.6 & 93.8 \\
15 & 14 & 6.2 & 100 \\
\hline \multicolumn{4}{c}{$\mathrm{N}=227$}
\end{tabular}

Figure 1. - Correlation between BMI and severe asymmetry in boys, $r(47)=-0.289, p=0.044$.

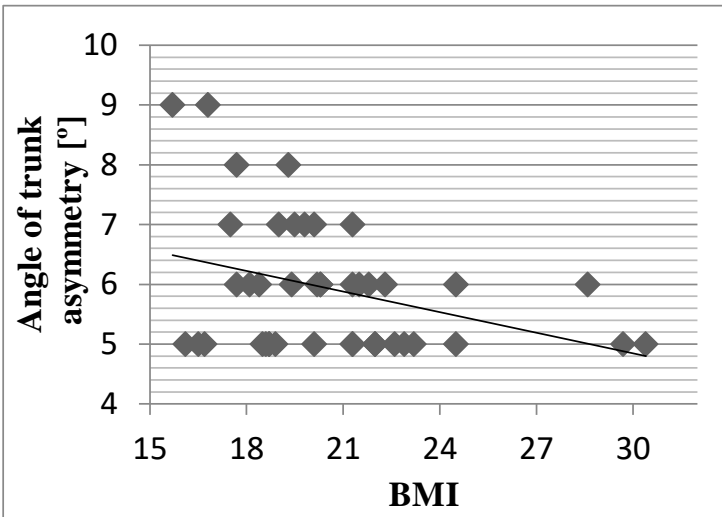

Of the children examined, $10.3 \%$ are left-handed and $89.7 \%$ right-handed. According to Holder [12], the proportion of left-handed and right-handed persons varies according to culture and geography. The number of right-handed persons is always higher, reaching $70 \%-95 \%$ of the population. Our study shows that in the case of the left-handed subjects, the mean asymmetry is $2.08^{\circ}( \pm 2.25)$, while in the case of the right-handed subjects is $2.56^{\circ}( \pm 2.71)$. According to the t-testfor independent samples, this difference is significant: $\mathrm{t}=2.812, \mathrm{p}=0.006$.

The distribution of the sample depending on the age and gender is presented in the Table II. The mean age of the subjects was $12.94( \pm 1.45)$ years: $13.12( \pm 1.41)$ years for boys and 12.73 ( \pm 1.48 ) for girls).

One of the questions included in the questionnaire was how pupils travel to school (by personal car, by public transport, by bicycle, on foot, or by other devices: skateboard, roller, etc.).

The Tukey post-hoc test revealed that the value of the trunk asymmetry is significantly lower in the subjects who are going on foot to school $\left(2.09^{\circ}\right.$, $\left.p=0.043\right)$ compared to the subjects who are going with personal cars (2.91을. No significant difference was found between subjects who go to school with cars and those using other means of transport $(\mathrm{p}=0.461$ for bus users, $p=0.999$ for cyclists, $p=0.997$ for skateboarders and trotter users).

The average physical activity score at the examined sample is $2.73( \pm 0.68)$. Boys have a higher physical activity score $(2.82 \pm 0.68)$, than girls $(2.62 \pm 0.67), \mathrm{t}=$ $3.258, \mathrm{p}=0.001$. A value between 1 and 2 is a mild 
physical activity, between 2 and 4 moderate, and over 4 intense physicalactivity[10].

To determine the relationship between trunk asymmetry and physical activity level, the Pearson correlation test was applied (Table III). According to this test, there is no correlation between these variables: $r=0.000, \mathrm{p}=0.998$. The results of the statistical analysis are similar, if we analyze separately the results of boys or girls. In the case of boys the result of the test is: $r$ $=0.055, p=0.376$, and for the girls $r=-0.014, p=$ 0.831 .

Table III. - Association between the trunk asymmetry and BMI, place of residence, physical activity level and the gender of the subjects

\begin{tabular}{|c|c|c|c|c|}
\hline $\begin{array}{c}\text { Dep. } \\
\text { variable }\end{array}$ & $\begin{array}{c}\text { Indep. } \\
\text { variable }\end{array}$ & $\mathrm{N}$ & $\begin{array}{c}\text { Pearson } \\
\text { Corr. }\end{array}$ & $\begin{array}{c}\text { Level of } \\
\text { sign. }\end{array}$ \\
\hline \multirow{4}{*}{ 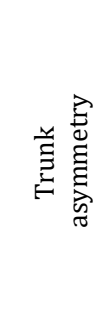 } & BMI & \multirow{4}{*}{487} & -.085 & .061 \\
\hline & $\begin{array}{l}\text { Place of } \\
\text { residence }\end{array}$ & & - .118 & .009 \\
\hline & $\begin{array}{l}\text { Level of } \\
\text { Physical } \\
\text { Activity }\end{array}$ & & .000 & .998 \\
\hline & $\begin{array}{l}\text { Gender of } \\
\text { the subj. }\end{array}$ & & .128 & .005 \\
\hline
\end{tabular}

Regarding the relationship between trunk asymmetry and BMI, the analyses were performed at first on the sample of boys $r=$ $0.085, \mathrm{p}=0.169$, then on the sample of girls $r=$ $0.058, \mathrm{p}=0.388$, and finally on the whole sample $r=-0.085, p=0.061$, but no significantcorrelation was found between the investigated variables. A very low and negative correlation was found between BMI and trunk asymmetry, but only for boys with severe asymmetries (Figure 1), $r=-0.289, \mathrm{n}=47, p=$ 0.044. Between these two above mentioned variables there is no correlation in case of the group of girls: $r=0.022, \mathrm{n}=60, p=0.868$.

\section{Discussion}

The relationship between severity of trunk asymmetry and BMI was analyzed by the Pearson correlation test. No significant correlation was found between these two variables with the exception of boys with severe asymmetries ( $\geq 5^{\circ}$ ). A study [13] found that BMI has a significant and negative relationship with trunk asymmetry in both boys and girls, meaning that smaller BMIs are associated with more severe asymmetry of the trunk. Other studies on this subject either confirm this relationship between BMI and asymmetry [14] or reject it [15].

The physical activity score at the evaluated sample is $2.73( \pm 0.68$ ), being significantly lower $t=-5.222, p=$ 0.000 , compared to the reported score $(2.89 \pm 0.64)$ by an other study [16]. At the same time, several studies also reported higher physical activity scores (3.1 $( \pm$ $0.60), 3.2( \pm 0.60), 3.05( \pm 0.68))[17,18,19]$.

No significant correlation was found between physical activity score and trunk asymmetry $r=0.000, \mathrm{p}=$ 0.998 . Some studies confirm the relationship between physical activity and trunk asymmetry [20], others (including our study) do not confirm this hypothesis [21].

There is a relationship between the severity of the trunk asymmetry and the practice of certain sports or performance sports, rather than between the severity of the asymmetry and the level of general physical activity $[22,23]$.

A study [21] concluded that „physical activity can be both a protective factor and a risk for postural changes. Possibly, factors such as the type of sport practiced, the volume of weekly training, time of practice and the way the activity is performed can influence the type of musculoskeletal response."

In our study, we found that the prevalence and severity of trunk asymmetry is significantly higher in subjects living in urban areas, than in those living in rural areas. This fact was also reported in 2012 [24]. They studied the influence of environmental and behavioral factors on the development and on the progression of idiopathic scoliosis in school-age children.

In the case of left-handed children, the severity of the trunk asymmetry is significantly lower than in righthanded children. Also, a study [3] found a relationship between trunk asymmetry and the handedness in children of Armenian, Albanian and Greek nationality.

\section{Conclusions}

Analyzing the results of this study, we can draw the following conclusions:

- There was a low correlation between severe trunk asymmetry and BMI in the boys group; 
- In the case of subjects who travel to school on foot, the degree of asymmetry is lower than in those who travel by car;

- In subjects living in rural areas, asymmetry is lower than in those living in urban areas;

- In the sample included in the study, there is no correlation between BMI and the angle of rotation of the back, but if we analyzed severe asymmetry in boys, we found a significant correlation between the two variables;

- Although boys are more active in terms of physical activity level, however, neither in their case nor in the girls was any correlation between the level of physical activity and the severity of the trunk asymmetry;

- In the left-handed subjects the severity of the back asymmetry is lower than in the case of the right subjects.

\section{References}

1. Grivas T. B., Vasiliadis E. S., Koufopoulos, G., Segos, D., Triantafyllopoulos, G., Mouzakis V. (2006). Study of trunk asymmetry in normal children and adolescents. Scoliosis, $1(19)$.

2. Rogala E. J., Drummond D. S., Gurr J. (1978). Scoliosis: incidence and natural history. A prospective epidemiological study. The Journal of Bone and Joint Surgery. American Volume, 60(2), 173-176.

3. Grivas T. B., Kasartzian A., Christin M., Mihas C., Aggouris C., Triantafyllopoulos G., et al. (2012). Study of back trunk asymmetry in children from three ethnic groups and correlation with their handednessx. Scoliosis, 7(Supl 1), 074. 4. Grivas T. B., Vasiliadis E., Mouzakis V., Mihas C., Koufopoulos G. (2006). Association between adolescent idiopathic scoliosis prevalence and age at menarche in different geographic latitudes. Scoliosis, 1(9).

5. Bunnell W. P. (1993). Outcome of Spinal Screening. Spine, 18(12), 1572-80.

6. Grivas T. B., Vasiliadis E. S., Mihas C., Savvidou O. (2007). The effect of growth on the correlation between the spinal and rib cage deformity: implications on idiopathic scoliosis pathogenesis. Scoliosis, 14(2), 11.

7. Patias P., Grivas T. B., Kaspiris A., Aggouris C., Drakoutos E. (2012). A review of the trunk surface metrics used as Scoliosis and other deformities evaluation indices. Scoliosis, $5(12)$.

8. Montgomery F., Persson U., Benoni G., Willner S., Lindgren B. (1990). Screening for scoliosis. A cost-effectiveness analysis. Spine, 15(2), 67-70.

9. Tyrakowski M., Czaprowski D., Szczodry M., Siemionow K. (2016). Cobb angle measurements on digital radiographs using Bunnell scoliometer: Validation of the method. Journal of Back and Musculoskeletal Rehabilitation.

10. Kowalski K., Crocker P., Donen R. (2004). The Physical Activity Questionnaire for Older Children (PAQ-C) and Adolescents (PAQ-A) Manual. Saskatchewan, Canada: College of Kinesiology, University of Saskatchewan.
11. Bunnell W. P. (1984). An objective criterion for scoliosis screening. Journal of Bone and Joint Surgery. American volume., 66(9), 1381-7.

12. Holder M. K. (1997). Why are more people right-handed? (S. American, Interviewer)

13. Grivas T. B., Burwell R. G., Mihas C., Vasiliadis E. S., Triantafyllopoulos G., Kaspiris A. (2009). Relatively lower body mass index is associated with an excess of severe truncal asymmetry in healthy adolescents: Do white adipose tissue, leptin, hypothalamus and sympathetic nervous system influence truncal growth asymmetry? Scoliosis, 4(13).

14. Hershkovich O., Friedlander A., Gordon B., Arzi H., Derazne E., Tzur D., et al. (2014). Association between body mass index, body height, and the prevalence of spinal deformities. The Spinal Journal, 14(8), 1581-7.

15. Nery L. S., Halpern R., Nery P. C., Nehme K. P., Stein A. T. (2010). Prevalence of scoliosis among school students in a town in southern Brazil. Sao Paulo Medical Journal, 128(2), 69-73.

16. Muratova V. N., Islam S. S., Demerath E. W., Minor V. E., Neal W. A. (2001). Cholesterol screening among children and their parents. Preventive Medicine, 33, 1-6

17. Ernst M. P., Pangrazi R. P. (1999). Effects of a physical activity program on children's activity levels and attraction to physical activity. Pediatric Exercise Science, 11, 393-405.

18. Mahon A. D., Anderson C. S., Hipp M. J., Hunt K. A. (2003). Heart rate recovery from submaximal exercise in boys and girls. Medicine and Science in Sports and Exercise, 35, 2093-2097.

19. MacKelvie K. J., Petit M. A., Khan K. M., Beck T. J., McKay H. A. (2004). Bone mass and structure are enhanced following a 2-year randomized controlled trial of exercise in prepubertal boys. Bone, 34, 755-764.

20. McMaster M. E., Lee A. J., Burwell G. (2015). Physical activities of Patients with adolescent idiopathic scoliosis (AIS): preliminary longitudinal case-control study historical evaluation of possible risk factors. Scoliosis, 10(6).

21. Sedrez J. A., Zaniratti da Rosa M. I., Noll M., da Silva Medeiros F., Candotti, C. T. (2015). Risk factors associated with structural postural changes in the spinal column of children and adolescents. Revista Paulista de Pediatria, 33(1), 72-81.

22. do Espirito Santo A., Guimarães L. V., Galera M. F. (2011). Prevalence of idiopathic scoliosis and associated variables in schoolchildren of elementary public schools in Cuiabá, state of Mato Grosso, 2002. Brazilian Journal of Epidemiology, 14(2), 347-356.

23. Meliscki G. A., Monteiro L. Z., Giglio C. A. (2011). Postural evaluation of swimmers and its relation to type of breathing. Fisioter Mov, 24, 721-728.

24. Muminagic S., Bisanovic S., Mehic S., Sivic, S. (2012). Way of Life as Emphasizing Factors in the Progression of Idiophatic Scoliosis in Adolescence Era. Mater Sociomed, 24(3), 182-185. 